\title{
Redes de amistad, paisanaje y venalidad de limeños en torno a los hábitos de las Órdenes Militares a finales del siglo XVII*
}

por

\author{
Francisco Andújar Castillo \\ Universidad de Almería
}

\begin{abstract}
A partir de una metodología que se fundamenta en el cruce de múltiples fuentes documentales y en destacar el valor del capital relacional en las dinámicas políticas y sociales en el Antiguo Régimen, se estudian las redes de amistad y paisanaje que los limeños tejieron a finales del siglo XVII para conseguir los honores de caballeros de las Órdenes Militares. Se analizan los vínculos existentes y cómo articularon redes para conseguir las cruces de las Órdenes y comprar los cargos de gobierno, justicia y hacienda de América que por entonces vendía la monarquía desde Madrid.

Palabras Clave: Órdenes Militares; reinado de Carlos II; venalidad; Lima; redes de poder.
\end{abstract}

Cómo citar este artículo / Citation: Andújar Castillo, Francisco, "Redes de amistad, paisanaje y venalidad de limeños en torno a los hábitos de las Órdenes Militares a finales del siglo XVII", Revista de Indias, LXXVIII/272 (Madrid, 2018): 79-112. https://doi.org/10.3989/ revindias.2018.003

\section{INTRODUCCIÓN}

Las investigaciones sobre la nobleza, y en particular las relativas al segmento social de los caballeros de hábito de las Órdenes Militares, han conocido un renovado desarrollo en los últimos años. Nos exime de abundar en el

* El presente estudio se ha realizado en el marco del Proyecto de Investigación de I+D Entre venalidad y corrupción en la monarquía hispánica durante el Antiguo Régimen, (HAR2014-55305-P), financiado por el Ministerio de Economía y Competitividad.

1 fandujar@ual.es, ORCID iD: http://orcid.org/0000-0002-3254-7153. 
extenso cúmulo de trabajos que han visto la luz en fechas recientes la remisión a los estudios recogidos en obras colectivas, como el último Congreso celebrado sobre las Órdenes ${ }^{2}$, las aportaciones de los que podríamos considerar como historiadores de referencia en la materia, Elena Postigo Castellanos ${ }^{3}$, Francisco Fernández Izquierdo ${ }^{4}$, y Fernando Andrés Robres ${ }^{5}$, las últimas contribuciones de jóvenes historiadores, Joseph Cerdá6, Agustín Jiménez Moreno ${ }^{7}$ y Domingo Marcos Giménez Carrillo ${ }^{8}$, así como otros que se han interesado por el estudio de los hábitos desde perspectivas como la del mundo de la milicia ${ }^{9}$. Por su parte, Portugal tiene en la figura de Fernanda Olival el principal icono de una renovada historiografía sobre las Órdenes Militares que presenta para nosotros especial interés, sobre todo para el período de unión de coronas ${ }^{10}$. Todos ellos, de un modo o de otro, vienen a ser herederos de los trabajos que sobre este campo iniciara hace años el gran maestro del modernismo español, Antonio Domínguez Ortiz, faro y guía señero de la historia social del Antiguo Régimen ${ }^{11}$. Para el caso de América, la magna obra de Guillermo Lohmann Villena aún no ha sido superada, pues los estudios que han aparecido con posterioridad no han aportado grandes novedades respecto a lo que expusiera en su día el historiador peruano ${ }^{12}$.

No obstante, el estudio de los caballeros de las Órdenes Militares tiene por delante aún un extenso campo de investigación a partir de diversos elementos de reflexión que, grosso modo, podríamos sintetizar en dos: por un lado, una obligada renovación metodológica que desarrolle líneas de trabajo específicas para el análisis del enorme corpus documental existente en el Archivo Histórico Nacional, en especial los denominados «expedientillos» y los expedientes de pruebas; de otra parte, y en relación con esa misma documentación, la necesidad de realizar un acercamiento a esas fuentes a partir de un análisis crítico de las mismas, algo que buena parte de la historiografía - sobre todo la menos especializada - no sólo no ha hecho sino que incide

2 Rivero Rodríguez, 2009.

3 Postigo Castellanos, 1988.

4 Fernández Izquierdo, 2003: 141-163; 2004: 11-60; 2005: 189-230.

5 Andrés Robres: 2002: 97-140. Artículo publicado en un monográfico de la revista Studia Histórica que aborda la historiografía de las Órdenes Militares en la Edad Moderna.

6 Cerdá i Ballester, 2014.

7 Jiménez Moreno, 2009: 155-171.

8 Giménez Carrillo, 2016.

9 Rodríguez Hernández, 2012: 415-443.

10 Olival, 2004: 95-116.

11 Domínguez Ortiz, 1976: 217-256; 1979: 181-187; 2000: 1157-1176.

12 Lohmann Villena, 1993. 
una y otra vez manteniendo posiciones que se limitan a una mera «descripción» del contenido de esos documentos. Así, pocos han sido los estudios, más allá de los emanados de las plumas de los autores citados más arriba, que han reflexionado sobre la forma en que se hacían unas pruebas que inquirían sobre la legitimidad, hidalguía, limpieza de sangre y oficios de los candidatos. Como se sabe, no fueron muchos los aspirantes a caballeros reprobados tras someterse al proceso de pruebas. Las cifras que aporta Elena Postigo para el reinado de Felipe IV hablan de poco más de medio centenar, entre las tres Órdenes castellanas de Santiago, Calatrava y Alcántara y, según su estimación, a pesar de que hubo más reprobados cuyos expedientes no se conservan, su cuantía no sobrepasaría el tres o cuatro por ciento del total ${ }^{13}$. Tampoco fueron muchos los que vieron cómo sus expedientes de pruebas quedaban retenidos por haberse detectado algunas tachas en sus «calidades».

Lo cierto es que más allá de los casos de reprobaciones, suspensiones temporales de pruebas y de la actividad de los conocidos «linajudos» que intervinieron para sacar provecho mediante la extorsión a los candidatos a estos honores, muy poco sabemos de dos elementos fundamentales que tuvieron una participación decisiva en las pruebas para caballeros: los informantes - habitualmente dos, caballero y religioso - designados por el Consejo de Órdenes para indagar sobre la limpieza de sangre e hidalguía de los aspirantes a caballeros, y los testigos que deponían en las preguntas con las que los informantes trataban de averiguar si tales aspirantes eran dignos de vestir el hábito de una Orden Militar.

Está fuera de toda duda que, con el tiempo, las pruebas para verificar la nobleza y limpieza de los candidatos a ingresar en las Órdenes se acabaron codificando, sistematizando en exceso y, a la altura del siglo XVIII, pocos procesos debieron acabar en reprobación o suspensión. Probablemente tuvo un peso decisivo en ello la distancia temporal con las posibles manchas «originales» de sangre judía o mora, una relajación en las formas de realizar las comprobaciones testificales, pero también, al margen de la tradición y de los requerimientos propios para el ingreso en las Órdenes, una mayor impronta del valor del «servicio», al menos en un plano comparable al de los requerimientos de nobleza y limpieza. Es probable que sucediera para los hábitos algo similar a lo que acaeció con las hidalguías que, como mostró I. A. A. Thompson, los memoriales de servicios de los que pretendían comprarlas ya en el siglo XVIII dejaron de esgrimir los principios de «lealtad»y «fidelidad»

13 Postigo Castellanos, 1988: 168-169. 
para sustituirlos por otros más relacionados con virtudes burguesas como las de «utilidad»y «bien público» ${ }^{14}$.

En la dirección apuntada nos parece esencial un análisis de lo que fueron las pruebas de hábito en su evolución temporal hasta transformarse en un procedimiento análogo a los juicios de residencia que, como ha señalado Tamar Herzog, tuvieron ante todo un sentido ritual, plasmado en prácticas mecánicas y reiterativas que se sucedían en el tiempo y que solían concluir en unos dictámenes poco lesivos para los intereses de los enjuiciados ${ }^{15}$. En el caso de los hábitos, tal cual ha sido interpretado por Jean Pierre Dedieu, las pruebas para el ingreso en diferentes instituciones de la monarquía, así como las que se hacían para las Órdenes Militares, se habrían transformado en ritos que casi siempre finalizaban en resultados positivos, porque progresivamente se fue buscando demostrar las calidades de los aspirantes más que ejercer un auténtico método de control sobre el origen social de éstos ${ }^{16}$. Idénticas consideraciones ha planteado María del Mar Felices de la Fuente cuando ha analizado las «cedulas de diligencias» e «informes reservados» que en algunas ocasiones la Cámara de Castilla recababa de los corregidores antes de elevar consultas al rey sobre los aspirantes a obtener títulos nobiliarios ${ }^{17}$. Sus observaciones sugieren que esos procesos de averiguación, con frecuencia estuvieron dirigidos por los mismos aspirantes a los títulos, y que los deponentes fueron elegidos entre sus propias clientelas para asegurarse testificaciones favorables, siempre similares entre sí y con idénticas fórmulas que evidenciaban que lo que se iba a declarar se había pactado previamente. Sobre esas bases, habría que profundizar en el estudio de la intervención en las pruebas de los propios candidatos a vestir los hábitos, esto es, analizar hasta qué punto los testigos que se interrogaban habían sido seleccionados por los informantes designados por el Consejo de Órdenes o si, por el contrario, éstos desarrollaron su labor tutelados o dirigidos por quienes se sometían a esas pruebas.

Tal reflexión, que significa tanto como plantear el problema de la posible manipulación o intervención por parte de los propios actores sociales de las pruebas que se realizaban sobre sus personas, constituye el punto de partida de las consideraciones que presentamos en las páginas siguientes. Lo hacemos desde un prisma que tiene su fundamento en el análisis del papel que desempeñaron los testigos en las pruebas de hábito, una problemática que Elena

\footnotetext{
14 Thompson, 2012: 294.

15 Herzog, 2000: 15-52.

16 Dedieu, 2002: 202.

17 Felices de la Fuente, 2011: 266.
} 
Postigo Castellanos ya abordó en su estudio sobre los caballeros de las Órdenes Militares en el siglo XVII, y por la cual pocos autores se han interesado posteriormente. Las escasas excepciones se encuentran en un estudio de Martine Lambert-Georges ${ }^{18}$ y en el meritorio trabajo de Thomas Glesener sobre los flamencos en las Órdenes Militares durante el siglo XVIII ${ }^{19}$.

El presente estudio analiza los vínculos establecidos entre un conjunto de individuos con intereses comunes en un momento dado, examinando el tipo de relación establecida entre ellos, el contenido de dicha relación y sus consecuencias o implicaciones. Se trata de un planteamiento derivado del análisis de redes sociales, cuyo aparato teórico ha sido ampliamente desarrollado en múltiples estudios ${ }^{20}$ y que en los últimos veinte años ha ofrecido relevantes aportaciones al conocimiento de las dinámicas sociales, políticas y económicas en la Edad Moderna ${ }^{21}$. Tomando como referencia dicho planteamiento teórico - que como es sabido ofrece múltiples vías de desarrollo- y formas de representación gráfica ${ }^{22}$, esta investigación presenta una aplicación empírica de tal modelo a un caso concreto a partir de fuentes documentales inéditas, utilizadas a través de una metodología específica y original.

Nuestro punto de partida se centra en el análisis de las testificaciones que se hicieron sobre un grupo de doce limeños -0 residentes en Lima en el momento de iniciarse dichas pruebas - en las postrimerías del siglo XVII, concretamente entre los años de 1692 y 1695, período en el que, según Lohmann Villena, tuvo lugar el mayor número de concesiones de hábitos de las Órdenes Militares a americanos de toda la Edad Moderna ${ }^{23}$. El criterio de selección ha sido totalmente aleatorio, escogiendo a esa docena entre los que consiguieron colgarse el hábito en esas fechas. La mayor parte de la documentación —expedientes de pruebas y «expedientillos»- se encuentra disponible en el Portal de Archivos Españoles y puede ser consultada directa-

18 Lambert-Gorges, 1982: 165-197.

19 Glesener, 2002: 167-188.

20 Mitchell, 1969. Boissevain, 1973. Requena, 1989; 2003. Imízcoz, 1996. Lozares, 1996. Scott, 1997. Dedieu y Moutoukias, 1998. Guerra, 2000. Herrero, 2000. Zúñiga, 2000. Molina, 2001. Bertrand, 2000. Ponce Leiva y Amadori, 2008. Bertrand y Lemercier, 2011.

21 Para el ámbito hispanoamericano véase, entre otros muchos, Lavalle, 1988. Bertrand, 1999; 2005. García León, 2007. Ibarra, 2007. Suárez, 2001.

22 Véase la última aportación sobre representación gráfica en el dossier coordinado por Emilie Senmartin y Michel Bertrand, "Introduction au dossier" "Analyse historique et réseaux. Réflexion sur la représentation graphique”, Les Cahiers de Framespa [en línea], 18 (2015), puesto en línea el 26 junio 2015, consultado el 13 septiembre 2015, URL: http://framespa. revues.org/3280.

23 Lohmann Villena, 1993: LXXXV. 
mente a través de Internet, circunstancia que tiene el peligro de considerarla como la única disponible sobre los individuos — caballeros de hábito - a investigar. Al respecto conviene advertir que no cruzar la información con otras fuentes documentales y la ausencia de las pertinentes formulaciones metodológicas, pueden dar como resultado estudios más que cuestionables que, lamentablemente, manan incluso de jóvenes investigadores que se les podría presumir expertos en lides de nuevas metodologías.

\section{El CONTEXTO. LA AVIDEZ DE LOS AMERICANOS POR LOS HÁBITOS DE Las Órdenes Militares Castellanas}

La demanda de hábitos por parte de las elites americanas, y en particular las limeñas en las postrimerías del siglo, a priori no debería presentar demasiados elementos diferenciales en relación con los mismos anhelos presentes en Castilla. El deseo de gozar del honor inherente a tal distinción era algo compartido por los grupos dirigentes de cualquiera de los territorios de la monarquía. Lo dejaba muy claro una consulta elevada al rey por el Consejo de Indias en 1684 a propósito de una petición de una merced de hábito para un vecino de Cartagena de Indias: «No duda el Consejo que los hábitos de las ordenes militares, si se consideraran por lo que tienen de religión según su instituto no son estimables, pero considerados por el honor, que es lo que principalmente solicita el que lo recibe, y en cuya atención los concede V. M., éste es estimable $[\ldots]{ }^{24}$.

Sin embargo, en el caso de Lima, concurrían en aquella coyuntura varias circunstancias que desataron una frenética demanda de títulos de caballeros y que hicieron que numerosos individuos emprendieran una carrera por conseguir dichos honores, bien desplazándose personalmente hasta Madrid «para pretender», bien encargando a los hábiles «agentes de negocios» que les consiguieran las mercedes de hábito que permitían iniciar los procesos de pruebas sobre las calidades de los aspirantes.

En primer término, cabe señalar el gran simbolismo que otorgaba el hábito de caballero en la sociedad del privilegio, la distinción social que comportaba el disfrute de un título honorífico que suponía el reconocimiento de un estatus nobiliario que, tras haber superado las pruebas de calidad, elevaba a sus poseedores hasta los altares de la jerarquía social. Se pedían los hábitos porque diferenciaban socialmente y de ahí que los grupos sociales con mayor

24 Consulta del Consejo de Indias de 24 de septiembre de 1684, Archivo General de Indias, Sevilla (AGI), Indiferente, legajo 790. 
poder económico pretendieran colgarse alguna de aquellas veneras que ornaban los mantos con las respectivas cruces. Riqueza sin honores de poco servía en aquella sociedad en la que el rango lo marcaba el prestigio social.

Por ello, en la ciudad de Los Reyes, los comerciantes agrupados en el Consulado fueron los principales aspirantes a estos honores. Sus demandas en estas últimas décadas del siglo XVII fueron constantes. Argumentos no le faltaban. De una parte sus servicios pecuniarios eran solicitados en repetidas ocasiones por la monarquía bajo diferentes formas, aunque casi siempre con contrapartidas en su favor. De otro lado, sus correligionarios en Sevilla, los mercaderes del Consulado hispalense, más cercanos al poder y con similares servicios, se veían agraciados con esas prebendas en proporciones muy superiores. Estando servido el agravio, los comerciantes limeños reclamaron una y otra vez un trato similar a los asentados en Sevilla. El propio virrey del Perú, Melchor de Navarra y Rocafull, se lo hizo saber al Consejo de Indias en 1681 cuando, tras hacer el comercio de Lima un servicio de 100.000 pesos, pidió sendos hábitos para el prior y cónsul del Consulado, quejándose de que a los limeños «por hallarse tan lejos de V.M. no les alcanzaban los influjos de su Real liberalidad como a los del comercio de Sevilla, no siendo inferior su celo ni desiguales los servicios [...] $\rangle^{25}$. Tanto el virrey como el propio Consejo tenían muy clara la necesidad de que el monarca derramase su gracia sobre los comerciantes: era el mejor medio para alentar nuevos servicios económicos en los años venideros. Pocos años después, en agosto de 1684, quien repetiría petición iba a ser el presidente interino del Consejo de Indias, el príncipe Vicente Gonzaga, quien solicitó recompensar con tres mercedes de hábito a quienes habían sido priores del Consulado de Lima, como forma de remunerar los servicios de carácter militar y financiero hechos por esta institución y sus miembros ${ }^{26}$.

Pero no todos los aspirantes a los hábitos procedían de ese núcleo de comerciantes del Consulado. Durante las últimas décadas de la centuria se desarrolló una descomunal almoneda de cargos de hacienda, justicia, gobierno y milicia, de la mano de los propios presidentes del Consejo de Indias, con el marqués de los Vélez a la cabeza, que lo presidió entre noviembre de 1688 y finales de septiembre de 1693. Ángel Sanz Tapia ha cuantificado esa almoneda para los cargos de gobierno, justicia y hacienda ${ }^{27}$. Pues bien, muchos de los compradores de esos oficios no volvieron a América tan sólo con el botín del empleo adquirido, pues convertidos de la noche a la mañana en corregi-

25 Consulta del Consejo de Indias de 17 de marzo de 1683, AGI, Lima, legajo 12.

26 Representación de Vicente Gonzaga al rey, 29 de agosto de 1684, AGI, Lima, legajo 12.

27 Sanz Tapia, 2009; 2011: 145-172; 2012: 63-90. 
dores, gobernadores o jueces, pretendieron regresar ornados con las veneras de las Órdenes Militares sobre sus pechos. Era, lo que se conocía en la época, como «servir con más decoro» o «ir condecorado» a los empleos que acababan de beneficiar. Es el caso de José Santa Cruz Gallardo quien recibió la merced «para que pase más condecorado a continuarlos [méritos] en el empleo de Presidente de la Audiencia de Chile y Capitán General de aquel Reino», cargos que no llegó a ocupar pues fueron adquiridos en régimen de «futura» que luego sería anulada ${ }^{28}$. No obstante, es probable que dicha merced de hábito más que para que pasara a Chile «más condecorado» formara parte de la negociación de compra de un puesto que le costó la considerable suma de 24.000 ducados $^{29}$.

Fuere el origen cual fuere, lo cierto es que todos los aspirantes a los hábitos de las Órdenes Militares eran individuos con recursos suficientes como para pagar los onerosos gastos de las pruebas y, en algunos casos, como para adquirir en el mercado privado las mercedes de hábito que les habilitaban para iniciar los procesos de control sobre sus calidades «sociales y profesionales». En suma, constituían un nutrido grupo de acaudalados miembros de las elites de Lima y de otras ciudades que vivieron una época en la que las necesidades de numerario de la monarquía le abrieron la puerta a la compra de toda suerte de cargos y honores, incluidos los preciados Títulos de Castilla que se pudieron adquirir a partir de 1681 sin acreditar grandes calidades ${ }^{30}$.

El primer paso para conseguir situarse en esa «mesocracia» de los caballeros de hábito era conseguir la merced. Al respecto, el cuadro 1 resulta bastante ilustrativo de los méritos con los que contaban estos limeños —al igual que otros muchos peninsulares y americanos - para acceder a aquellos títulos que constituían la antesala al inicio de las pruebas de calidad para ser proclamados como caballeros de una Orden Militar. Salvo Manuel Francisco Clerque, los que iban a ser investidos como caballeros no habían prestado servicios algunos a la monarquía como para ser distinguidos con tales honores. Nada de excepcional había en ello, pues cuando no había méritos personales las mercedes de hábito podían conseguirse, mayoritariamente, a través de tres vías, aunque hubo muchas más: en primer término, por transmisión familiar; en segundo lugar, al casar con una mujer que fuese poseedora de una merced dotal que haría caballero de una Orden Militar a quien casare con ella; y, por último, se podían obtener mercedes de hábito en el «mercado privado», si bien los propietarios de ellas debían contar con una autorización regia que

\footnotetext{
28 AGI, Chile, legajo. 168, fols. 159v.-161v.

29 Sanz Tapia, 2009: 457.

30 Maruri Villanueva, 2009: 207-240.
} 
aprobase la transmisión — «paso»— a terceros. A esas tres vías de obtención de mercedes se sumaba otra más simple que consistía en anotar en el despacho los tan manidos términos de «por sus méritos y servicios», sin que exis-

\section{CUAdro 1: ORIGEN de LAS MERCEDES DE HÁBITO}

\begin{tabular}{|c|c|c|}
\hline Nombre & $\begin{array}{c}\text { Servicios personales } \\
\text { previos }\end{array}$ & Origen de la merced de hábito \\
\hline J. Santa Cruz Gallardo & Ninguno & $\begin{array}{l}\text { «Servicios y méritos propios y he- } \\
\text { redados». Para que «pase más con- } \\
\text { decorado» a Chile }\end{array}$ \\
\hline Manuel F. Clerque & $\begin{array}{l}\text { Escribano Mayor de } \\
\text { Ayuntamiento de Lima }\end{array}$ & «En atención a sus servicios» \\
\hline Juan Luján Acuña & Ninguno & $\begin{array}{l}\text { «En atención a los servicios de sus } \\
\text { pasados» }\end{array}$ \\
\hline Diego José Quint & Ninguno & $\begin{array}{l}\text { Merced al Sargento Mayor José Be- } \\
\text { llido Trujillo que el } 11 \text { de enero de } \\
1694 \text { «resolví se pusiese en cabeza } \\
\text { de Don Diego Quint» }\end{array}$ \\
\hline Sancho de Londoño & Ninguno & $\begin{array}{l}\text { «En atención a los servicios de sus } \\
\text { pasados» }\end{array}$ \\
\hline Pedro Arnau Segarra & Ninguno & $\begin{array}{l}\text { Merced dotal dada en } 1655 \text { a Rodri- } \\
\text { go de Arce y Eraso «para quien ca- } \\
\text { sare con su hermana Eugenia de } \\
\text { Arce», con quien ha contraído ma- } \\
\text { trimonio Pedro Arnau. }\end{array}$ \\
\hline $\begin{array}{l}\text { Ambrosio de Salaman- } \\
\text { ca y Zabala }\end{array}$ & Ninguno & $\begin{array}{l}\text { «A Gregorio de Salamanca y Robles } \\
\text { para uno de sus hijos» }\end{array}$ \\
\hline Juan Vergara Pardo & Ninguno & $\begin{array}{l}\text { «En atención a los servicios de don } \\
\text { Lucas de Vergara su padre», del } \\
\text { Consulado de Lima }\end{array}$ \\
\hline José Santiago Concha & Ninguno & $\begin{array}{l}\text { «En atención a sus méritos y los de } \\
\text { su padre» }\end{array}$ \\
\hline $\begin{array}{l}\text { Juan Próspero Solís } \\
\text { Vango }\end{array}$ & Ninguno & $\begin{array}{l}\text { Merced al capitán Alonso Juan de } \\
\text { Valdés, y en } 1692 \text { «se pone en ca- } \\
\text { beza de su primo» Juan Próspero } \\
\text { Solís }\end{array}$ \\
\hline $\begin{array}{l}\text { Melchor Malo Molina, } \\
\text { marqués de Monterrico }\end{array}$ & Ninguno & «En atención a sus servicios» \\
\hline $\begin{array}{l}\text { Andrés Hidalgo Espi- } \\
\text { nosa }\end{array}$ & Ninguno & $\begin{array}{l}\text { Merced al marqués de la Vega para } \\
\text { Andrés Hidalgo, su sobrino }\end{array}$ \\
\hline
\end{tabular}

Fuente: Archivo Histórico Nacional, Madrid (AHN), expedientillos, 5743, 5729, 14302, 14320, 14308, 5217, 5694, 11466, 11492, 11415, 11413 y 14338. 
tiesen tales, procediendo más bien dichos honores del favor, del patronazgo o de prácticas oscuras más complejas de evaluar pues no han dejado evidencias documentales.

Que en aquellos tiempos el rey premiaba exclusivamente con estos honores a quienes le habían servido, es una afirmación que no se sostiene en la actualidad a la luz de las investigaciones más recientes ${ }^{31}$. El mencionado cuadro 1 lo corrobora plenamente. No hubo en el caso de los limeños servicios personales previos, pues las mercedes procedieron de las tres vías señaladas, entre las cuales, las que tenían su origen en hipotéticos parentescos de «primos» y «sobrinos», solían ser más bien producto de transacciones entre particulares.

REDES DE RELACIONES EN TORNO A LOS HÁBITOS DE LIMEÑOS: LA RECIPROCIDAD EN LAS TESTIFICACIONES

Fue, por tanto, en ese contexto en el que se produjo esa venta masiva de cargos y de honores, cuando los doce limeños escogidos pasaron sus pruebas para ser investidos como caballeros de las Órdenes Militares. En ellas comparecieron numerosos testigos que, como veremos, bien podrían ser calificados como «testigos de parte», más que como verdaderos colaboradores de los dos informantes que solía designar el Consejo de Órdenes para que acometieran el proceso de recabar las pruebas sobre el origen social - casi siempre inmaculado - de los aspirantes a los hábitos.

El problema de las relaciones entre testigos y aspirantes a los hábitos no es un asunto menor en el estudio sobre los caballeros de las Órdenes Militares, pues la existencia de vínculos podía ser decisiva para el éxito final de las indagaciones sobre las calidades de los aspirantes. Dicho de otro modo, a nuestro juicio, el estudio de la relación entre ambas partes, lejos de ser un tema accesorio, se ha de situar en el centro del análisis de los mecanismos de control sobre el origen social - las pruebas - que permitían que los aspirantes a los hábitos fuesen calificados como miembros del «selecto» grupo de caballeros de Santiago, Calatrava o Alcántara.

No obstante, seguir la pista de quienes testificaban sobre cada individuo que se sometía a las pruebas es labor ardua que tan solo es posible abordar aplicando un análisis «microhistórico» como método de aproximación a la complejidad del propio proceso. Las indagaciones realizadas en los municipios de origen del candidato y de sus padres y abuelos, maternos y paternos,

31 Giménez Carrillo, 2016. 
implicaban la participación en el proceso de pruebas de un elevado número de testigos que, en muchos casos, suponían una cifra superior al medio centenar de deponentes. Por ende, la reconstrucción del proceso exigiría una investigación no sólo sobre la documentación emanada de las «pruebas» sino en todos los lugares y archivos que fueron consultados por los informantes desplazados hasta los lugares de origen de los pretendientes a los hábitos. La tarea es casi titánica, si bien existen algunas vías alternativas para determinar hasta qué punto en los procesos de pruebas para los hábitos intervenían los propios interesados, e incluso hasta dónde el «ritual» podía estar dirigido por ellos mismos.

Una de esas vías se puede explorar en el caso de los pretendientes a hábitos que habían nacido en Indias, pues acostumbraban a solicitar que las pruebas, en lo tocante a sus naturalezas de origen, se hiciesen en Madrid por el conocido sistema de «patria común ${ }^{32}$. Se buscaba ahorrar costes y tiempo en las obtención de los hábitos pero también que no afloraran durante el proceso de pruebas posibles manchas, tales como el ejercicio de profesiones poco acordes con los principios nobiliarios. Las de comerciante, minero o traficante de esclavos no eran precisamente ocupaciones correspondientes al estatus nobiliario y, por tanto, lo mejor era ocultarlas con declaraciones «fieles» que testificaran en el sentido que interesaba a los candidatos para lograr los hábitos.

El estudio de los referidos doce expedientes de limeños de finales del siglo XVII revela que los testigos no fueron elegidos de forma voluntaria por los dos informantes designados por el Consejo de Órdenes sino que formaban parte de una trama articulada en torno a un grupo de aspirantes unidos entre sí por intereses comunes y con una identidad de origen también común, en este caso, limeños o residentes en la ciudad de Los Reyes. El interés mutuo, como es obvio, radicaba en la elaboración de respuestas al interrogatorio, de manera que todos declararan lo previamente acordado en favor del aspirante al hábito, pero de forma que no fuese algo gratuito sino dentro de la lógica de una red perfectamente organizada en la que el principio de reciprocidad debía vertebrar toda la actuación en cada una de las deposiciones de información. Quien comparecía como testigo en las pruebas de un aspirante a caballero, unos días después se veía sometido a esas mismas pruebas, figurando en este último caso como candidato a otro hábito.

El análisis de la documentación revela que todo estaba planificado y organizado, de modo que los informantes cuando iniciaban su labor en Madrid sabían claramente a dónde debían dirigirse y a qué testigos debían interrogar.

32 Postigo Castellanos, 1988: 161. 
Con extraordinaria celeridad obtenían las respuestas de varios testigos, de manera que en pocos días finalizaban su labor en la Corte. Siempre conseguían respuestas en los mismos términos, y de individuos que, aunque no hubiesen conocido directamente a los candidatos a los hábitos, «habían oído» acerca de su buena conducta, hidalguía y limpieza de sangre. Sin duda, la planificación del sistema de indagaciones debía estar dirigida por algunos elementos centrales de una red que con toda probabilidad se habría forjado desde el momento mismo en que cualquiera de sus elementos conseguía hacerse con la merced de hábito, puerta imprescindible de acceso a las pruebas.

Como hemos mostrado en otro estudio, relativo al acceso a la nobleza titulada del limeño Tomás González Galeano y de su hermano José ${ }^{33}$, todos los indicios apuntan a que, al menos en la coyuntura de finales del siglo XVII, hubo un intenso tráfico privado de mercedes de hábito de las Órdenes Militares castellanas. Dado que las mercedes de hábito no se podían enajenar, porque se podía incurrir en delito de simonía ${ }^{34}$, se solía recurrir a transacciones entre particulares, a la invención de hipotéticos familiares no directos, y a utilizar fórmulas tan extrañas en las transferencias de mercedes entre dos personas, previa licencia regia, como las de «poner en cabeza de», «señalar a», «nombrar a». Eran los conocidos «pasos de hábito», que cuando se producían con individuos ajenos al ámbito familiar venían a ser «traspasos» que posibilitaban que las mercedes recayesen en individuos ajenos a quienes habían sido recompensados por el soberano.

Pues bien, como señalamos, es muy probable que el proceso seguido por estos limeños comenzara con la obtención — en muchos casos «compra»—de la merced de hábito, y que tanto los que se desplazaban personalmente desde América hasta Madrid como los intermediarios que negociaban estos honores siempre trataran de asegurarse el éxito final de una operación que debía culminar con la investidura de caballero, pero que tenía sus fases decisivas en la propia obtención de la merced y en la realización de las pertinentes pruebas de «calidad».

En este caso, como es obvio, aludimos a los que se trasladaban personalmente a Madrid en pos de honores y, como veremos, de algo más. Su presencia en la Corte en aquellos años obedecía a la tradición de que el mejor método de alcanzar las mercedes, cargos y honores que se buscaban era ir «a pretender» directamente a Madrid. El largo viaje desde América a Sevilla o Cádiz y desde ahí hasta la capital de la monarquía, siempre se solía hacer con la bolsa bien repleta de monedas que encaminaran y facilitaran la pretensión

\footnotetext{
33 Andújar Castillo, 2013: 17-29.

34 Giménez Carrillo, 2011: 301-313.
} 
o pretensiones. Por ende, el conocimiento mutuo de los limeños no tenía por qué haberse forjado tan sólo en la capital virreinal sino que se habría consolidado durante el viaje, y sobre todo durante la dilatada estancia en la Corte, donde en ocasiones pasaban años hasta que se conseguían las «pretensiones» que les habían movido a emprender el largo camino desde virreinato del Perú. Una vez instalados en Madrid, provistos casi siempre de buenos caudales, lo mejor era moverse en un círculo de compatriotas, amigos o conocidos entre los que hubiera patrones que guiaran a estos pretendientes por los procelosos vericuetos del poder y de las relaciones, senderos imprescindibles para llegar hasta el favor regio. Se trataba pues de introducirse y acabar formando parte, aún de forma transitoria mientras duraba su estancia en España, de las redes de influencia que funcionaban en Madrid, siempre nucleadas en torno a lazos de amistad, parentesco, patronazgo y paisanaje, que contaban con miembros plenamente introducidos en cargos en la Corte y en las principales esferas de la alta administración de la monarquía.

Las testificaciones en las pruebas para la obtención de hábitos para los limeños considerados son inequívocas, en cuanto que se pueden considerar relaciones de poder o apoyos manifestados de manera deliberada hacia los pretendientes, máxime cuando comprobamos que esas relaciones estaban marcadas por vínculos de reciprocidad. El grafo 1 resulta clarificador de esos nexos ${ }^{35}$. De los doce «caballeros» escogidos, la mitad de ellos viajaron hasta Madrid para hacerse con la merced de hábito, pasar las pruebas y, al mismo tiempo, casi todos ellos, también para conseguir uno de los múltiples cargos que por entonces se enajenaban en la Corte ${ }^{36}$. Como se comprueba, buena

35 En el grafo aparecen representados los doce caballeros de hábitos estudiados y los testigos de sus pruebas como nodos. Las aristas que los relacionan parten de los testigos hacia los aspirantes a caballeros. Éstos últimos aparecen representados en nodos de tono más oscuro, frente a los que únicamente fueron testigos para los que hemos usado un tono más claro. Hemos introducido esta distinción a fin de que se puedan observar claramente quiénes fueron los pretendientes a los hábitos, ya que participaron a su vez como testigos en otras pruebas. También, con el objetivo de aclarar la representación, hemos variado el tamaño de los nodos en función del número de veces que testificaron en las pruebas de otros caballeros. Así pues, el marqués de Escalona, Manuel Francisco Clerque o los Londoño aparecen representados con un tamaño mucho mayor debido a que aparecen sistemáticamente en las pruebas de otros caballeros y constituían por ello piezas fundamentales de la red. Por último, señalar que únicamente hemos representado aquellos testigos que aparecen en más de tres pruebas de hábito. Esto deja fuera a decenas de declarantes que han sido incluidos en los análisis previos pero que hemos omitido de la representación gráfica debido a que son elementos periféricos cuya inclusión generaría demasiado «ruido» al añadir decenas de aristas alrededor del núcleo representado sin que ello supusiese ninguna otra modificación en su distribución.

36 Sanz Tapia, 2009. 
parte de ellos testificaron mutuamente en sus respectivos procesos de pruebas de calidad sobre su origen y oficios desempeñados, tanto por ellos mismos como por sus antepasados. Así, por ejemplo, José Santa Cruz Gallardo compareció como testigo en las pruebas de Manuel Francisco Clerque y este lo hizo en las de aquél ${ }^{37}$; José Santiago Concha depuso en las pruebas de Sancho de Londoño y éste lo hizo en las suyas ${ }^{38}$; de la misma forma recíproca se comportaron Juan Luján Acuña y José Santiago Concha ${ }^{39}$. Era, sin duda, la mejor forma de garantizar las aspiraciones de un grupo que tenía los mismos intereses comunes en que ninguna mácula pudiera impedir el buen fin de sus objetivos, que no eran otros que regresar a América investidos con la condición nobiliaria que otorgaba pertenecer a cualquiera de estas Órdenes Militares castellanas. Nada anormal en todo ello, pues, como veremos más adelante, estos van a ser algunos de los miembros más activos de una tupida red de individuos procedentes del virreinato del Perú, y más concretamente de Lima, que estuvo integrada por muchos más miembros que los citados hasta aquí.

Siguiendo con ese mismo grafo 1, se observa que esa presencia en las testificaciones de otros aspirantes a los hábitos no se produjo en algunos casos. La explicación es tan sencilla como que se trata de individuos que no viajaron hasta Madrid sino que encargaron la tramitación de sus expedientes a terceras personas, ora fuesen familiares, ora agentes de negocios e intermediarios especializados en estas materias. Así, Ambrosio de Salamanca no se desplazó hasta la Corte, pero en su lugar lo hizo su padre, Gregorio de Salamanca, quien comparecería en algunas de esas pruebas - concretamente en las de Manuel Francisco Clerque, Juan Próspero Solís y José Santa Cruz Gallardo-, en tanto que del recurso a intermediarios, tras haberles dado poder notarial en América, se valieron los restantes que no comparecieron personalmente en la Corte.

No hay que insistir demasiado en que las pruebas para lograr el hábito de caballero de cualquiera de las tres Órdenes castellanas constituían el segundo escollo a salvar, pues previamente los aspirantes debían haber conseguido la merced que les posibilitaba iniciar el proceso de pruebas. Diferentes autores han demostrado claramente que una cuestión era la titularidad de la merced

37 Archivo Histórico Nacional, Madrid (AHN), Órdenes Militares, Santiago, exp. 7602. AHN, Órdenes Militares, Santiago, exp. 1982.

38 AHN, Órdenes Militares, Calatrava, exp. 2399. AHN, Órdenes Militares, Alcántara, exp. 823 .

39 AHN, Órdenes Militares, Alcántara, exp. 842. AHN, Órdenes Militares, Calatrava, exp. 2399. 
y otra bien distinta quien acababa siendo investido caballero ${ }^{40}$. Tenemos pocas dudas de que algunas de las mercedes procedían del referido «tráfico privado» de honores. No de otro modo se puede entender que varios de los doce casos escogidos se hicieran con sendas mercedes para ellos y para sus familiares en el mismo año. Así, nada menos que tres hermanos Salamanca Zabala, consiguieron mercedes de hábito en 1693, lo mismo que lo hicieron en 1695 los hermanos Santiago Concha, José, Pablo y Gregorio, este último «a instancia de la condesa de Lemos» ${ }^{41}$; por su parte, los hermanos Vergara Pardo, Lucas y Juan, hijos de un comerciante limeño se hicieron con sendas mercedes en el año de 1694.

Lo que parece evidente es el origen del mundo del comercio de algunos de estos individuos que lograron los hábitos en estos años. De los doce seleccionados sabemos con certeza que Ambrosio de Salamanca Zabala, que recibió el hábito de caballero en 1694, era hijo de Gregorio de Salamanca Robles, comerciante limeño ${ }^{42}$, quien en ese mismo año consiguió nada menos que cuatro mercedes de hábito, una para sí mismo y tres que destinó a sus hijos Gregorio, Domingo Felipe y Salvador ${ }^{43}$. Idéntica dedicación al comercio tenía el padre de Juan Vergara Pardo, pues la merced de hábito se le dio por los servicios de su padre y «al celo y fineza con que lo están continuando en el Consulado de Comercio de Lima» ${ }^{44}$. El mismo Vergara en su relación de méritos fechada en 1701 ratificaría el poder y dedicación de su padre y abuelo que habían desempeñado los cargos de prior y cónsules de dicho Consulado ${ }^{45}$.

LOS NUEVOS CABALLEROS DE HÁBITO: EL HILO DE UNIÓN EN TORNO A LOS HONORES Y A LA VENALIDAD

Analizar con detalle los datos reunidos acerca de los doce caballeros que hemos tomado como base para tratar de reconstruir la trama de limeños en la Corte ocuparía un espacio que excedería, con mucho, los límites de esta aportación. No obstante, como veremos, la obtención del hábito no fue el único objetivo de su presencia en Madrid. El cruce con documentación ajena a los

\footnotetext{
40 La más reciente aportación se encuentra en: Giménez Carrillo, 2016.

41 AHN, Ódenes Militares, expedientillo 11491.

42 Turiso Sebastián, 2002: 328.

43 AHN, Órdenes Militares, expedientillos 5694, 5695, 5696 y 5697.

44 AHN, Órdenes Militares, expedientillo 11466.

45 AGI, Indiferente, legajo 135, n. ${ }^{\circ} 133$.
} 
propios expedientes de pruebas ilustra claramente lo que fue una estrategia bien definida que perseguía un doble fin: adquirir honores, en este caso, los hábitos, pero también los cargos que la monarquía «beneficiaba» en aquella coyuntura.

En las dos últimas décadas del siglo XVII se desarrollaba en Madrid, a través de la vía del Consejo de Indias, una descomunal almoneda que afectaba fundamentalmente a los empleos políticos, de hacienda y de justicia. Entre otros muchos, los estudios de Ángel Sanz Tapia ${ }^{46}$, Michel Bertrand ${ }^{47}$, y Chandler y Burkholder ${ }^{48}$ han abordado por extenso la venalidad de esos cargos, respectivamente en los tres ámbitos citados. El objetivo de esa enorme almoneda fue aportar unos recursos extraordinarios a una hacienda regia siempre necesitada de numerario, máxime en los años estudiados cuando la Guerra de los Nueve Años absorbía buena parte de los ingresos de la monarquía ${ }^{49}$.

De los doce individuos cuyos procesos de pruebas hemos estudiado, nueve de ellos, además del hábito, se desplazaron hasta la Corte o se valieron de intermediarios que negociaran sus asuntos para comprar cargos. Incluso, se puede observar una estrategia muy bien calculada que se iniciaba con la compra o beneficio del cargo, para a continuación presentarse a las pruebas del hábito, ya en calidad de «servidor de la monarquía». El cruce con otras fuentes documentales ajenas a los expedientes de pruebas, revela que cuando José Santiago Concha se sometió a las pruebas para caballero de Calatrava en 1695 y cuando testificó en favor de los limeños que iban a pasar idénticas pruebas de sus calidades durante esos años, se presentó como alcalde del crimen de la Audiencia de Lima ${ }^{50}$, cargo que había adquirido en diciembre de 1692 por 22.000 pesos, suma que incluía la exención para poder casar con natural de esa circunscripción y para ejercer en la misma jurisdicción en que había nacido $^{51}$. Y, como hemos señalado, lo propio hizo José Santa Cruz Gallardo, que se sometió a las pruebas presentándose como Capitán General de Chile - cargo que no desempeñaría - tras haberlo adquirido, si bien en 1702 consiguió amortizar esa inversión fallida al enjugarla en otra de mayor cuantía, por la fabulosa suma de 80.173 pesos que pagó por la compra a perpetuidad del puesto de Tesorero y Blanquecedor de la Casa de Moneda de Lima ${ }^{52}$. Y

46 Sanz Tapia, 2009.

47 Bertrand, 1999.

48 Burkholder y Chandler, 1984.

49 Andújar Castillo, 2012: 395-422.

50 AHN, Órdenes Militares, Calatrava, exp. 2399.

51 AGI, Contaduría, legajos. 156 y 158.

52 Andújar Castillo, 2008: 253. La operación venal de Santa Cruz Gallardo fue de mayor calado pues unos meses después de conseguir el hábito, en abril de 1695, su padre, Luis 
cuando en 1694 se realizaron las pruebas para caballero de Alcántara de Diego José Quint, éste compareció, con toda solemnidad, como contador del Tribunal Mayor de Cuentas de Lima ${ }^{53}$, cargo que había adquirido en diciembre en diciembre de 1692 por la suma de 22.000 escudos de a 10 reales de plata $^{54}$.

El nexo de unión con la venalidad se pone de manifiesto igualmente en los restantes casos estudiados. Manuel Francisco Clerque, que era escribano mayor del ayuntamiento de Lima, adquirió en 1692, por tanto, antes del hábito de caballero, los corregimientos de Trujillo y Cañete por 4.000 y 2.000 pesos de a 10 reales de plata respectivamente, más una cantidad adicional de 1.000 pesos más por la facultad para ejercer el de Trujillo a pesar de haber nacido allíi5. Por su parte, Juan Luján Acuña, compró en ese mismo año de 1692, antes de pasar las pruebas para caballero, la futura de los corregimientos de Tarija y Tarma por 5.000 pesos, los cuales luego no llegó a ejercer pues falleció antes de tomar posesión ${ }^{56}$.

Con posterioridad al «ennoblecimiento» adquirió su cargo Juan Vergara Pardo, el cual pagó en 1702 la fortuna de 7.000 doblones de a dos escudos de oro, por el puesto de Contador Mayor del juzgado de bienes de difuntos de Lima y su jurisdicción ${ }^{57}$. Y lo propio hizo Juan Próspero Solís, aunque su inversión en un puesto fue más tardía y formó parte de una operación más compleja, pues en marzo de 1707 su hermano Toribio pagó 38.000 pesos, de ellos 18.000 al contado, por la adquisición para sí del grado de maestre de campo, capitán general de Guadalajara y presidente de su audiencia, y por la concesión a su hermano Juan Próspero de una plaza de oidor de la audiencia de Chile, con dispensa de menor de edad, y con la condición de que no se expresase en documento alguno «la cantidad que corresponde al beneficio de la plaza de oidor» ${ }^{58}$.

El caso de Melchor Malo de Molina es tal vez el más singular de todos, pues en su persona se culminaba el ascenso social de una familia de las más

Santa Cruz Padilla, compró el título nobiliario de conde de San Juan de Lurigancho por 22.000 ducados. Cif. en Maruri Villanueva, 2009: 214.

53 AHN, Órdenes Militares, Alcántara, exp. 1239.

54 AGI, Contaduría, legajo 156.

55 AGI, Contaduría, legajo 158. Ambos cargos los adquirió con facultad de poderlos pasar a otra persona - revender - y acabaron en manos de García de Híjar Mendoza, conde de Villanueva de Soto, quien le pagó 14.000 pesos, consiguiendo así un notable beneficio de esa reventa privada de los cargos públicos. Cif. Sanz Tapia, 2009: 421.

56 AGI, Contaduría, legajo 158.

57 AGI, Indiferente, legajo 525, libro 1. Andújar Castillo, 2008: 254.

58 AHN, Estado, legajos 532 y 874. 
Cuadro 2: Los CABAlleros y EL BENEFICIO DE CARGOS Y HONORES

\begin{tabular}{|c|c|c|c|}
\hline Nombre & $\begin{array}{c}\text { Cargos beneficiados } \\
\text { (en pesos de a } 8 \text { reales) }^{(a)}\end{array}$ & Merced & Caballero \\
\hline $\begin{array}{l}\text { J. Santa Cruz } \\
\text { Gallardo }\end{array}$ & $\begin{array}{l}\text { Gobernador y Capitán General de Chi- } \\
\text { le (1694-07-30): } 24.000 \text { pesos (No } \\
\text { ejerció) }{ }^{(b)} \text {. } \\
\text { Tesorero y blanquecedor de la Casa de } \\
\text { la Moneda de Lima: } 80.173 \operatorname{pesos}^{(\mathrm{c})}\end{array}$ & $\begin{array}{l}1693-10-05 \\
1702-06-05\end{array}$ & Santiago, 1694 \\
\hline $\begin{array}{l}\text { Manuel Francisco } \\
\text { Clerque }\end{array}$ & $\begin{array}{l}\text { Corregidor de Cañete y Trujillo } \\
\text { (1692): } 8.125 \text { pesos }^{(\mathrm{d})} \text { (No ejerció) }\end{array}$ & $1692-9-29$ & Santiago, 1694 \\
\hline Juan Luján Acuña & $\begin{array}{l}\text { Corregidor de Tarija y Tarma (1692-4- } \\
\text { 24): } 6.250 \text { pesos }^{(\mathrm{e})} \text { (No ejerció) }\end{array}$ & $1692-06-23$ & Alcántara, 1693 \\
\hline Diego José Quint & $\begin{array}{l}\text { Contador del Tribunal Mayor de Lima } \\
(1692-12-2): 27.500 \text { pesos }^{(f)}\end{array}$ & 1693-09-14 & Alcántara, 1694 \\
\hline Sancho de Londoño & & 1693-06-02 & Alcántara, 1693 \\
\hline Pedro Arnau Segarra & & $1687-07-20$ & Santiago, 1694 \\
\hline $\begin{array}{l}\text { Ambrosio de } \\
\text { Salamanca }\end{array}$ & & $1693-12-15$ & Santiago, 1694 \\
\hline Juan Vergara Pardo & $\begin{array}{l}\text { Contador Mayor del Juzgado de Bie- } \\
\text { nes de Difuntos de Lima y su jurisdic- } \\
\text { ción (1702-03-12): } 52.500 \text { pesos }\end{array}$ & $1694-05-25$ & Calatrava, 1694 \\
\hline $\begin{array}{l}\text { José Santiago } \\
\text { Concha }\end{array}$ & $\begin{array}{l}\text { Alcalde del crimen de Lima (1692-12- } \\
\text { 12): } 18.000 \text { pesos }^{(\text {h) }}\end{array}$ & $1693-11-18$ & Calatrava, 1695 \\
\hline Juan Próspero Solís & $\begin{array}{l}\text { Oidor de Santiago de Chile (1707-05- } \\
\text { 24): } 38.000 \text { pesos }^{(i)}\end{array}$ & 1684 / 1692 & Calatrava, 1693 \\
\hline $\begin{array}{l}\text { Melchor Malo } \\
\text { Molina, marqués de } \\
\text { Monterrico }\end{array}$ & $\begin{array}{l}\text { Compra el título nobiliario de marqués } \\
\text { de Monterrico (1687-03-26): } 30.000 \\
\text { pesos }^{(j)}\end{array}$ & $1688-02-12$ & Calatrava, 1694 \\
\hline $\begin{array}{l}\text { Andrés Hidalgo } \\
\text { Espinosa }\end{array}$ & $\begin{array}{l}\text { Oidor de la Audiencia de Chile (1692- } \\
\text { 12-05): } 13.750 \text { pesos }^{(\mathrm{k})}\end{array}$ & $1692-12-15$ & Alcántara, 1695 \\
\hline
\end{tabular}

(a) Todas las cantidades han sido transformadas a valores de pesos de a ocho reales.

(b) Sanz Tapia, 2009: 457.

(c) AGI, Indiferente, legajo 525, libro1.

(d) Sanz Tapia, 2009: 420.

(e) AGI, Contaduría, legajo 156.

(f) AGI, Contaduría, legajo 156.

(g) AGI, Indiferente, legajo 525, libro 1.

(h) AGI, Contaduría, legajos 156 y 158.

(i) La cantidad pagada por el puesto de oidor se desconoce pues su hermano Toribio lo adquirió, junto con los puestos de capitán general y presidente de la audiencia de Guadalajara, más el grado de maestre de campo, pactando el silencio sobre el importe del beneficio de la plaza de oidor, AHN, Estado, legajos 532 y 874 .

(j) AGI, Indiferente, legajo 497, libro 51.

(k) Burkholder y Chandler, 1984: 206. 
acaudaladas de Lima que en generaciones anteriores había sabido invertir las plusvalías de sus actividades mercantiles en honrosos puestos como los de Alguacil Mayor de Lima, en la compra de una regiduría en el cabildo de esa misma ciudad, así como en puestos militares. Melchor Malo compró en 1685 - aunque el despacho se le dio dos años después - por 30.000 pesos el título de marqués de Monterrico al virrey del Perú, el duque de la Palata, a quien se le había concedido facultad para enajenarlo en $1683^{59}$. Como solía ser habitual, del título se eliminó cualquier rastro que pudiera delatar el origen venal de la merced, y en su lugar se pusieron los méritos de su padre y abuelos. Tras comprar el título, para reforzar aún más su prestigio, consiguió en $1688^{60}$ una merced de caballero de cualquiera de las tres Órdenes Militares, y tras elegir la orden de Calatrava pasó las pruebas en $1694{ }^{61}$.

Por último, otro caso que merece un comentario extenso es el de Andrés Hidalgo de Paredes, natural de Charcas aunque originario por parte materna de Lima. Podría considerarse como paradigma de las pautas utilizadas por estos indianos para conseguir cargos y honores valiéndose de mil argucias, en este caso con el elemento añadido del cambio de apellidos intencionado, ora fuese para comprar una plaza de oidor, ora para conseguir la merced de hábito. En efecto, en 1692 se hizo con un puesto de oidor de la audiencia de Chile por un «servicio» de 11.000 escudos de a 10 reales de plata. En aquella ocasión se nombró como Andrés Hidalgo de Paredes y Espinosa ${ }^{62}$, y dijo ser abogado en la audiencia de La Plata ${ }^{63}$. Para que no sonase el ruido del dinero en la obtención de aquella merced regia, el depósito del dinero en la tesorería del Consejo de Indias lo hizo uno de los intermediarios más activos en aquel momento, Isidoro Garma Puente, quien abonó los 110.000 reales en calidad de «beneficio secreto» ${ }^{64}$. Conseguida la plaza de oidor permaneció en Madrid hasta lograr - más bien comprar- la merced de hábito que le encumbraba hasta el goce del honor de caballero de la orden de Alcántara. Unos nuevos apellidos facilitaron la tarea. En enero de 1695 el marqués de la Vega - Baltasar Rivadeneira Zúñiga - consiguió de Carlos II una merced de hábito «para su sobrino Andrés Hidalgo de Espinosa y Rivadeneyra» ${ }^{65}$. De ese modo venían a coincidir los apellidos de los supuestos parientes. La ficción

\footnotetext{
59 AGI, Indiferente, legajo 497, libro 51.

60 AHN, Órdenes Militares, expedientillos 11413.

61 AHN, Órdenes Militares, Calatrava, exp. 1476.

62 Burkholder y Chandler, 1984: 206.

63 AGI, Indiferente, legajo 498, libro 54.

64 AGI, Contaduría, legajo 156.

65 AHN, Órdenes Militares, exp. 14338. El entrecomillado es nuestro.
} 
del parentesco se comprueba cuando en las pruebas para vestir el hábito a las que se sometió en ese mismo mes de enero, ninguno de los testigos aludió a su tío marqués, ni el apellido Rivadeneyra se pudo encontrar entre la genealogía familiar de sus ascendientes ${ }^{66}$. No tenemos duda alguna de la que la obtención de la merced que le habilitaba para pasar las pruebas para ser investido como caballero de Alcántara fue producto de una transacción privada entre Andrés Hidalgo y el marqués de la Vega. Además, cuando pasó las pruebas, en especial las de Indias que las hizo en Madrid «por de paso», ninguno de los testigos señaló que fuese oidor de Chile, pues el cargo había sido comprado de forma tan secreta como que ni siquiera se había acercado por la covachuela del Consejo de Indias para depositar el dinero. Por ende, fueron exclusivamente los caudales con los que Andrés Hidalgo debió de llegar hasta Madrid, aunque eso sí, convenientemente acompañados de intencionados cambios de apellidos, los que le permitieron comprar su plaza de oidor y la merced de hábito que le posibilitó regresar a Chile como caballero de Alcántara.

A tal efecto, lo más granado del colectivo de limeños instalado en la Corte y con excelentes intermediarios, depuso en su favor. De un total de 18 testigos que declararon en Madrid por conocerle de Perú, la mitad habían hecho el viaje con los mismos fines que Andrés Hidalgo: comprar empleos para ejercer en América y conseguir hábitos de las órdenes castellanas. En la nómina de testigos figuraron individuos como Juan del Corral Calvo, que iba a comprar en la misma audiencia de Chile en junio de 1695 una plaza de oidor, aunque a un precio inferior, 8.000 pesos $^{67}$. Los restantes testigos formaban parte de la misma trama. Entre los que participaron del mercado de compra de cargos y honores estaban José Santa Cruz Gallardo, Cristóbal Messía y Valenzuela - que andaba en Madrid adquiriendo para sí el gobierno de Buenos Aires y el título de conde de Sierra Bella para su padre-, Juan Pérez de Urquizu, José Santiago Concha, Manuel Francisco Clerque y Francisco Tamayo Mendoza, este último, también presente en la Corte a fin de comprar el título de marqués de Villahermosa, honor que conseguiría un año después de participar como testigo en las pruebas de Andrés Hidalgo ${ }^{68}$. Y desde luego no faltaron entre los deponentes sobre la calidad y sangre noble de Hidalgo, los Londoño - padre e hijo-, así como el gran patrón de aquella red de limeños, Iñigo Acuña, marqués de Escalona, mayordomo de la reina madre.

\footnotetext{
66 AHN, Órdenes Militares, Alcántara, exp. 723.

67 Burkholder y Chandler, 1984: 207.

68 AGI, Indiferente, legajo 525-1.
} 
El mercado venal en el que participaron la mayor parte de los peruanos analizados refuerza la tesis que venimos manteniendo de que las mercedes de hábito que permitieron el acceso a la condición de caballeros tuvieron en muchos casos un origen venal, procedente de transferencias entre particulares. En esa tarea sería capital la participación de intermediarios que dispusieran de las relaciones necesarias para conocer quiénes contaban con mercedes de hábitos transferibles y los precios que pedían por ellas. El papel de alguno de estos mediadores, como Diego de Villatoro, ha sido resaltado por Ángel Sanz Tapia y, para los caballeros que nos ocupan, lo ha destacado Rafael Guerrero Elecalde en relación a Melchor Malo de Molina ${ }^{69}$. Pero también sabemos que fue el agente de negocios que tramitó y negoció en 1692 la compra por parte de José Santiago Concha de la plaza de alcalde del crimen de la audiencia de Lima $^{70}$.

RELACIONES PERSONALES Y VENALIDAD: LA TRAMA DE TESTIGOS EN LAS PRUEBAS DE HÁBITO

La existencia de una tupida trama de relaciones e intereses, primero para la obtención de las mercedes y luego para superar las pruebas de hábito, nos parece clave para entender todo el proceso que convergía en el ascenso social de estos indianos ávidos de honores y de cargos que conseguían por dinero, pero también disponiendo de los contactos e influencias necesarias para que todo convergiese en el éxito de sus pretensiones.

El grafo 1 muestra la red de testigos que participaron en Madrid en las pruebas de hábito correspondientes a las naturalezas de Indias de los doce pretendientes estudiados. Hay que ponderar al respecto que el número de testigos fue muy desigual pues osciló entre los ocho y los treinta por caballero, dependiendo del celo en las comprobaciones de los informantes o del interés de los mismos por alargar las pruebas para percibir los correspondientes emolumentos.

Para una mayor claridad expositiva, para corregir esas diferencias y otorgar mayor visibilidad a los elementos nodales de la red, hemos representado en el grafo tan sólo a aquellos individuos que fueron testigos en las pruebas de tres o más aspirantes al título de caballeros. En principio, todos debían conocer a los pretendientes, bien por haber residido en Lima o en el virreinato del Perú con anterioridad, o bien por estar presentes en esos momentos en

\footnotetext{
69 Guerrero Elecalde, 2012: 133.

70 AGI, Contaduría, legajo 158.
} 


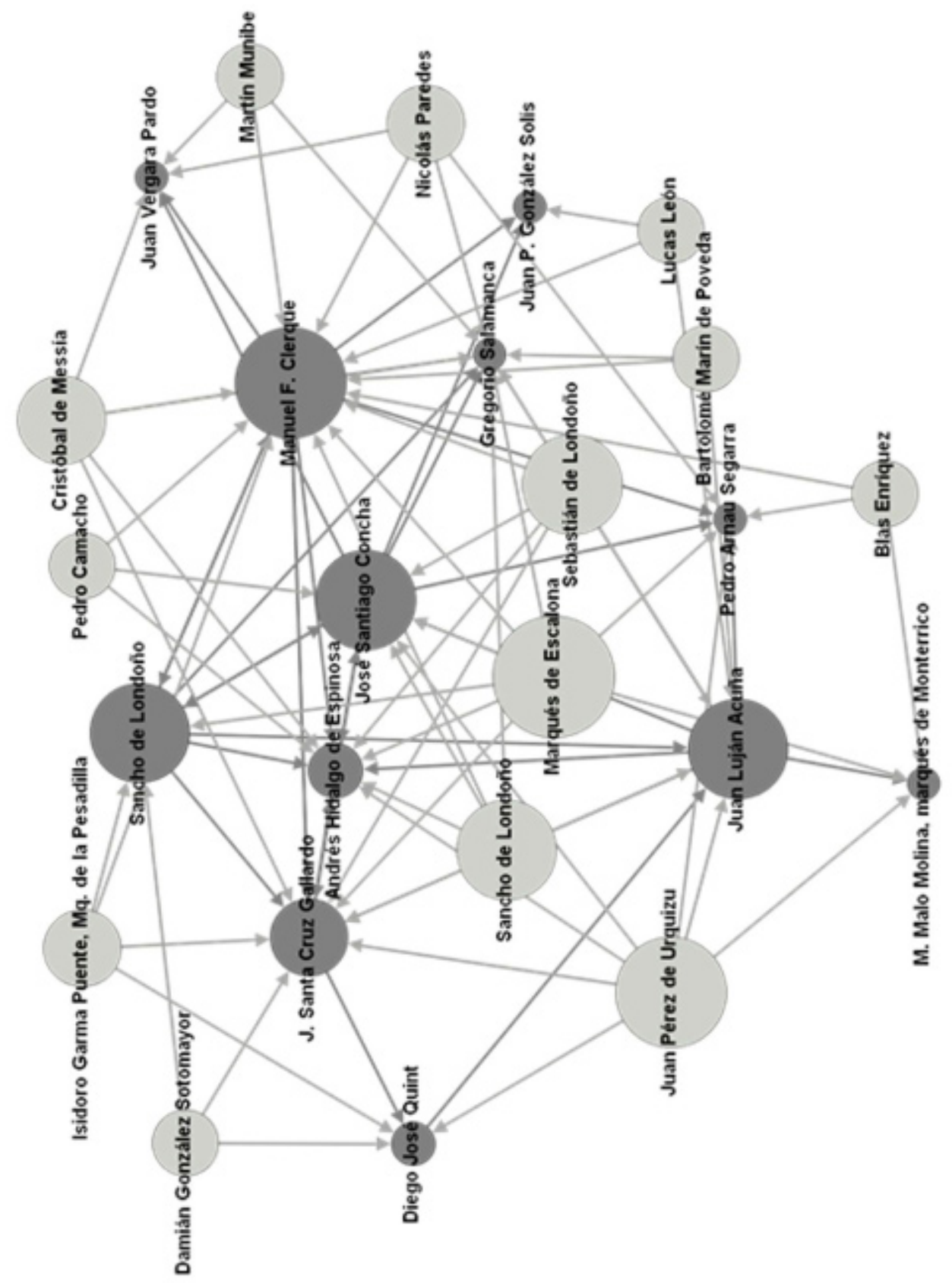


Madrid en sus asuntos particulares que, como hemos mostrado, eran idénticos a los que aspiraban a ser investidos como caballeros. Cuestión bien distinta fue que en la práctica los conociesen realmente pues en muchos casos los testigos respondían a las preguntas de los informantes siguiendo un ritual preestablecido en el que sus contestaciones al interrogatorio formaban parte de algo previamente pactado, bien con los propios sujetos que se sometían a las pruebas, bien con los agentes de negocios comisionados a tal efecto.

El grafo 1 presenta dos características que merecen un extenso comentario. La primera, la presencia de unos personajes centrales que intervienen en un mayor número de pruebas y, la segunda, no representada, la existencia de un nexo de relación en la mayor parte de esos testigos en torno a la venalidad de los cargos. En cuanto a esta segunda consideración, lo que se aprecia es que aunque podríamos afirmar que los lazos de conocimiento o de amistad se podrían haber forjado en Lima o en el viaje a España, en realidad los vínculos de unión y la formación de esa red de relaciones tenía otro elemento de relación en torno a ese interés común que había sido el objeto fundamental de su largo viaje, que no era otro que el de la compra de cargos y/o honores. La relación con la venalidad, con las tramas de información que permitían el acceso a los espacios de enajenación de los cargos, se corrobora aún más cuando comprobamos que entre los testigos figuraron no ya solo aspirantes a los hábitos sino individuos que estaban asentados en algunos de los principales espacios de poder de la Corte, y que habían accedido a esos cargos y honores por el mismo método del «servicio pecuniario» que utilizaban ahora los indianos aspirantes a los hábitos y a los empleos para ejercer en América.

El principal elemento común entre los individuos implicados, su relación con la venalidad, no se refleja en el grafo 1 pero resulta clave en toda la conformación de la red, tal y como se muestra en el cuadro 3 que incluye tan sólo los que figuraron como testigos en tres o más procesos de pruebas, y que viene a poner de manifiesto que el lazo del dinero, del poder económico, en este caso por la vía de la compra de cargos, fue una de las palancas de movilidad social ascendente más importantes del Antiguo Régimen.

Como se puede apreciar, la red estaba integrada por individuos que se habían desplazado desde América hasta Madrid para negociar sus «pretensiones» pero también por elementos nodales que decían haber residido en Lima o en el virreinato de Perú en años anteriores y que se presentaban ahora como testigos en las pruebas de calidad de los aspirantes a los hábitos. Más arriba hemos mostrado la reciprocidad en las testificaciones de quienes perseguían el mismo fin, que no era otro que avalarse mutuamente para conseguir vestir el hábito de caballero. Sin embargo, al margen de ellos, otros nombres sobre- 


\section{CuAdro 3: Testigos CON MAYOR NÚMERo DE TESTIFICACIONES EN LAS PRUEBAS DE HÁBITO}

\begin{tabular}{|c|c|c|c|}
\hline Testigo & $\begin{array}{l}\text { N. }{ }^{\circ} \text { de } \\
\text { testific. }\end{array}$ & Cargos / honores beneficiados (en reales) & $\begin{array}{c}\text { Fecha } \\
\text { compra }\end{array}$ \\
\hline $\begin{array}{l}\text { Iñigo Acuña Escalona, } \\
\text { marqués de Escalona }\end{array}$ & 8 & Título de Marqués de Escalona (804.250 reales) $)^{\text {(a) }}$ & 1679 \\
\hline Juan Pérez de Urquizu & 7 & $\begin{array}{l}\text { Alcalde del crimen de la audiencia de Lima ( } 220.000 \\
\text { reales)(b) }\end{array}$ & 1692 \\
\hline Manuel F. Clerque & 7 & Corregidor de Cañete y Trujillo (65.000 reales) $)^{\text {(c) }}$ & 1692 \\
\hline Juan Luján Acuña & 6 & Corregidor de Tarma y Tarija (50.000 reales) $)^{(\mathrm{d})}$ & 1692 \\
\hline José Santiago Concha & 6 & Alcalde del crimen de Lima (18.000 pesos) $)^{(\mathrm{e})}$ & 1692 \\
\hline Sancho de Londoño & 6 & & \\
\hline Sebastián de Londoño & 6 & & \\
\hline Cristóbal Messía Valenzuela & 5 & $\begin{array}{l}\text { Gobernador de Buenos Aires y Presidente de la Au- } \\
\text { diencia de La Plata que no ejerció y se le permutó por } \\
\text { el corregimiento de Riobamba ( } 40.000 \text { reales })^{(\mathrm{f})} \text {. }\end{array}$ & 1695 \\
\hline $\begin{array}{l}\text { Isidoro Garma Puente, } \\
\text { marqués de La Pesadilla }\end{array}$ & 4 & $\begin{array}{l}\text { Alguacil Mayor del Consejo de Aragón perpetuo } \\
(800.000 \text { reales })^{(\mathrm{g})}\end{array}$ & 1678 \\
\hline José Santa Cruz Gallardo & 4 & $\begin{array}{l}\text { Gobernador y Capitán General de Chile: } 24.000 \text { pesos. } \\
\text { No ejerció. } \\
\text { Tesorero y blanquecedor de la Casa de la Moneda de } \\
\text { Lima: } 80.173 \text { pesos }^{(h)}\end{array}$ & $\begin{array}{l}1694 \\
1702\end{array}$ \\
\hline Nicolás Paredes Armendáriz & 4 & Futura de oidor de Lima (precio abonado en secreto) $^{(i)}$ & 1695 \\
\hline Martín José Munibe & 3 & $\begin{array}{l}\text { Corregidor de Canes y Canches }(5.000 \text { pesos })^{(\mathrm{j})} \\
\text { Título de marqués de Valdelirios («muy gruesa canti- } \\
\text { dad de dinero») }^{(\mathrm{k})}\end{array}$ & $\begin{array}{c}1697 \\
1703\end{array}$ \\
\hline Blas Enríquez & 3 & $\begin{array}{l}\text { Alguacil Mayor del Consejo de Cruzada perpetuo } \\
(600.000 \text { reales })^{(1)}\end{array}$ & 1691 \\
\hline Damián González Sotomayor & 3 & Eclesiástico & \\
\hline Bartolomé Marín de Poveda & 3 & Eclesiástico & \\
\hline Lucas León & 3 & & \\
\hline Pedro Camacho & 3 & & \\
\hline Gregorio de Salamanca & 3 & & \\
\hline
\end{tabular}

(a) AGS, Contaduría Mayor de Cuentas, 3. época, legajo 1796: 13.

(b) AGI, Indiferente, legajo 498, libro. 54. La suma pagada incluía, además, la licencia para casar con natural de la jurisdicción en donde iba a ejercer, AGI, Contaduría, legajo 158.

(c) AGI, Contaduría, legajo. 158. No ejerció esos cargos pues luego los vendió a García de Híjar Mendoza, conde de Villanueva de Soto. Cif. en Sanz Tapia, 2009: 420.

(d) AGI, Contaduría, legajo 156.

(e) AGI, Contaduría, legajos 156 y 158.

(f) Después de invertir esa suma en el gobierno de Buenos Aires se le suspendió la merced al ordenar el rey que no se beneficiase ese puesto, por lo que se le ofreció a cambio la devolución del dinero pagado o la permuta por otro cargo. Debió optar por esta segunda solución pues se le dio la futura del corregimiento de Riobamba en abril de 1697, AGI, Buenos Aires, legajo 4, libro 11.

(g) AGS, Estado, libro 430.

(h) AGI, Indiferente, legajo 525, libro 1.

(i) Burkholder y Chandler, 1984: 206.

(j) Sanz Tapia, 2009: 443.

(k) Felices de la Fuente, 2012: 370.

(1) AGS, Estado, libro 430. 
salen en la nómina de deponentes en las pruebas de los doce caballeros limeños seleccionados. Algunos de ellos requieren un comentario particular.

Sin duda, el «gran patrón» - pues compareció en ocho testificaciones del total de doce pruebas analizadas - parece ser Iñigo Acuña Castro, marqués de Escalona. Su posición de privilegio en el palacio real, en calidad Mayordomo Mayor de la reina madre, y el hecho de haber residido en el virreinato del Perú, le confirieron un papel central en todas las pruebas de los hábitos de limeños que se tramitaron en esos años finiseculares. Además, no actuó solo sino junto a su sobrino, Juan Luján Acuña, beneficiario de una merced de hábito y testigo en las mismas pruebas en las que deponía su tío. Por otro lado, relaciones no le faltaban, pues su hija había casado con Alonso Carnero, el que fuera Secretario del Despacho Universal de Carlos II entre 1694 y julio de 1695, fecha esta última en que fue nombrado consejero de Indias ${ }^{71}$.

Sus negocios debían exceder, con mucho, a ese puesto que desempeñaba de Mayordomo de la reina madre. Que sepamos, el dinero que pagó en 1679 por el título nobiliario de marqués de Escalona es la mayor fortuna abonada por una merced de ese tipo a lo largo del siglo XVII y primera mitad del $\mathrm{XVIII}^{72}$. Nacido en Perú, pues su padre había sido corregidor de Cuzco y Potosí, no sabemos en qué fecha exacta regresó a España para hacerse con la mayordomía de la reina madre. Lo cierto es que en esos años de finales de la centuria estuvo presente en la gran mayoría de las testificaciones, y que en especial favoreció a sus sobrinos, Juan - éste incluido entre los doce elegidos para estudiar sus pruebas- José Lino ${ }^{73}$ y Diego Acuña Luján, no sólo consiguiendo la merced para ellos sino prestándoles dinero para comprar los cargos que adquirieron en esos mismos años en que se vistieron como caballeros. En el testamento de Juan de Acuña Luján, fechado el 12 de febrero de 1696 en Cartagena de Indias, éste declaró mantener una deuda total de 22.648 pesos con su tío Iñigo de Acuña, quien se los había prestado para sus pretensiones — de cargos y honores - durante el tiempo que había estado en Madrid ${ }^{74}$.

71 AGS, Gracia y Justicia, legajo 814.

72 No se encuentra en la obra de María del Mar Felices ninguna cuantía similar en los títulos obtenidos por compra en la primera mitad del siglo XVIII ni en los que estudia relativos al reinado de Carlos II.

73 José Lino Luján Acuña benefició en régimen de futura el corregimiento de Jauja en 1693 por una suma de 4.000 pesos, cargo que no llegó a ejercer al anularse años dicha futura. Cif. en Sanz Tapia, 2009: 437.

74 AGI, Contratación, legajo 567, n. ${ }^{\circ}$ 1, r. 1. En concreto, en dicho testamento, declaraba deberle del total de esa cantidad 7.124 correspondientes a la que había empleado en el corregimiento de Tarama. 
Un segundo elemento central en los procesos de testificaciones se encuentra en la figura de Juan Pérez de Urquizu, un individuo que, al igual que José Santiago Concha, además de letrado, pertenecía a una familia de comerciantes ${ }^{75}$. Se trata de un caso singular por cuanto su primer objetivo para viajar a España lo consiguió en diciembre de 1692 al adquirir una plaza de alcalde del crimen de la Audiencia de Lima en 220.000 reales. Sin embargo, permaneció en Madrid largo tiempo, hasta agosto de 1695, pues en septiembre de ese año se registró para embarcar hacia América $^{76}$, no sin antes haber intervenido como testigo de las pruebas para caballero de José Santiago Concha, el comprador de otra alcaldía del crimen en la citada Audiencia, el mismo día que él y por idéntico importe. Esa dilatada estancia en la Corte y el permanente contacto con los limeños que habían llegado en pos de cargos y honores le hicieron omnipresente en buena parte de las testificaciones en las pruebas para caballeros.

Por su parte, Cristóbal Messía Valenzuela, hijo de Diego Cristóbal, oidor de Lima, y luego presidente de Charcas, se desplazó a Madrid con el doble objetivo de comprar el cargo de gobernador de Buenos Aires - que finalmente se le permutó por el corregimiento de Riobamba-y adquirir para su padre el título nobiliario de conde de Sierra Bella. En la Corte supo moverse con gran habilidad pues entró en contacto con Diego de Villatoro, el principal mediador en la venta de cargos por aquellos años, así como con Juan Araujo, un oficial de la Secretaría del Perú del Consejo de Indias, que también ejerció labores similares a las de «agentes de negocios» como Villatoro. En noviembre de 1695 Cristóbal Messía dio poder a Araujo para que sacase los despachos del Título de Castilla de su padre «poniendo todas las cláusulas y circunstancias que vocalmente 77 le tengo comunicadas, sin que otra persona pueda tener intervención $\rangle^{78}$.

Otro testigo residente en Madrid, Blas Enríquez, cuya testificación en las pruebas de limeños se fundamentaba en «haber residido en Chile tres años» ${ }^{79}$, intervino como mediador en la tramitación de hábitos de las Órdenes Militares. En otro estudio hemos documentado su mediación en la consecución del hábito de Antonio Centeno, y su relación con otro de los testigos, Bartolomé Marín de Poveda, otro personaje capital en la red, pues regresó del virreinato

75 Sanz Tapia, 2012: 80.

76 AGI, Contratación, legajo 5456, n. ${ }^{\circ}$ 3, r. 45.

77 El entrecomillado es nuestro. El término «vocalmente» sin duda se refería a silenciar el dinero pagado por el despacho del título.

78 Archivo Histórico de Protocolos de Madrid (AHPM), Protocolo 13317, fol. 539 r.

79 AHN, Órdenes Militares, Santiago, exp. 248. 
del Perú bien provisto de caudales, producto de actividades corruptas realizadas junto a su tío Bartolomé González de Poveda, presidente de la audiencia de La Plata y arzobispo de Charcas, y que le permitieron situarse en la proximidad del rey como capellán de honor de la Capilla Real ${ }^{80}$.

Entre la nómina de testigos identificamos a Isidoro Garma Puente, marqués de La Pesadilla desde $1698^{81}$, que vivió en Lima durante 28 años, otro sujeto central que debió dedicarse a menesteres ajenos a su cargo de Alguacil Mayor del Consejo de Aragón, adquirido en 1678 por la fortuna de 80.000 escudos. Bien relacionado desde ese puesto, conocedor de los limeños por su larga estancia americana, éstos tuvieron en su persona un elemento de referencia. Así, como hemos anotado más arriba, en 1692 intervino en el beneficio secreto de una plaza de oidor de la audiencia de Chile para Andrés Hidalgo Paredes, pues por su mano se ingresaron en la tesorería del Consejo de Indias 110.000 reales de plata, a pesar de que Hidalgo se encontraba en aquel momento en Madrid 82.

Lo mismo puede decirse de los Londoño, Sancho, y su padre Sebastián, quienes no adquirieron cargos para servir en América pero que participaron en los mismos expedientes de pruebas, interviniendo en la mitad de los casos estudiados. Ninguno de los dos regresó a Indias sino que al menos durante un tiempo se asentaron en Madrid y se dedicaron a tareas de mediación con «pretendientes» americanos. Ambos debieron llegar desde Lima con gruesos caudales pues se dedicaron a prestar dinero a indianos que se habían desplazado hasta la Corte para pretender cargos y honores ${ }^{83}$. A la altura del año 1698, fallecido ya su padre, Sancho de Londoño mantuvo una intensa actividad para cobrar deudas que diversos eclesiásticos mantenían con el negocio familiar. Y en ese mismo ámbito recibió poderes desde Lima para negociar pretensiones de eclesiásticos en Madrid, como el que le otorgó en 1696 Agustín Bernardo de Quirós, cura y vicario de Guarochiri para que, en remuneración de sus servicios y los de sus padre, pidiera la «merced o mercedes que por bien tuviere el rey darle» ${ }^{84}$.

\footnotetext{
80 Andújar Castillo y Giménez Carrillo, 2011: 203.

81 Barrio Moya, 1993: 137-146.

82 Andrés Hidalgo Paredes compareció a su vez como testigo en varias pruebas de nobleza para obtener el hábito de caballero.

83 AHPM, Protocolo 13695, fol. 230 r.

84 AHPM, Protocolo 13695, fol. 475 r.
} 


\section{CONCLUSiones}

El conjunto de relaciones presentado permite hablar de una red de vínculos de diversa naturaleza (parentesco, amistad, paisanaje) y contenido (dinero, honores, cargos) ${ }^{85}$, establecidos en primera instancia en el virreinato del Perú - en especial en Lima - ampliados luego probablemente durante el viaje a España y, sobre todo, durante la larga estancia en la Corte a la espera de conseguir los anhelados honores y adquirir los cargos que se enajenaban por aquellos años de fines del siglo XVII. Todos los actores sociales tenían intereses comunes, por una parte en las relaciones de reciprocidad en las testificaciones, de manera que unos apoyaban a otros en la misma dirección de aseverar unas calidades nobiliarias comunes y, por otro lado, en la configuración de una estrategia que tuvo la clave del éxito final en la obtención de los mismos objetivos. De este modo, conseguían ascender socialmente, al tiempo que adquirían los empleos para ejercer en Indias que les permitirían alcanzar un poder político que consolidaría a estas familias entre una elite indiana que vería así incrementado su poder económico mediante el desempeño de cargos que le reportaban prestigio y riqueza. En un marco de intercambio de favores, las testificaciones en las pruebas para caballero de las Órdenes Militares debieron ser uno, entre muchos, de los elementos de conexión entre los actores sociales. Relaciones de amistad, de paisanaje, más interés común en acreditar un pasado familiar de limpieza de sangre, hidalguía y desempeño de oficios honrosos, convergían en unas testificaciones que necesariamente deberían ir en la misma dirección de preclaros orígenes de todos los pretendientes a ingresar en dichas corporaciones nobiliarias.

En las páginas precedentes hemos tratado de mostrar el fuerte peso de los vínculos personales en la conformación de estos grupos de elite en América, en concreto de la elite criolla limeña. Pero más importante aún nos parece destacar la relevancia que en dicha configuración tuvo el dinero, ese mismo que posibilitó estrechar los vínculos entre los miembros de la red y que sirvió para obtener mercedes honoríficas — hábitos de las Órdenes Militares - y los cargos que se vendían en la Corte en aquella coyuntura de finales del siglo XVII. Los vínculos entre los individuos que participaron en las pruebas para caballeros fueron tan evidentes como que el resultado final de las mismas siempre habría estado condicionado por unos trámites que, amén de ser concebidos como un ritual a repetir en cada caso, emanaban de testigos que no se pueden calificar como de neutros, antes al contrario, como primeros y

85 Sobre los conceptos de «naturaleza», «contenido» y «valor» de los vínculos que integran una red social, véase Ponce Leiva y Amadori, 2008: 26. 
principales interesados en que los interrogatorios se ajustasen a las pautas preestablecidas desde que se acometía el proceso de averiguación de calidades.

\section{BiBLIOGRAFÍA}

Andrés Robres, Fernando, "Dos siglos de historiografía sobre la orden de Montesa en la Edad Moderna (1801-2000)", Studia historica. Historia moderna, 24 (Salamanca, 2002): 97-140.

Andújar Castillo, Francisco, Necesidad y venalidad. España e Indias, 1704-1711, Madrid, Centro de Estudios Políticos y Constitucionales, 2008.

Andújar Castillo, Francisco, "Venalidad y gasto militar: sobre la financiación de la guerra de los Nueve Años", Agustín González Enciso (ed.), Un Estado Militar. España, 1650-1820, Madrid, Actas, 2012: 395-422.

Andújar Castillo, Francisco, "Hacerse noble a finales del siglo XVII. Las contradicciones de la jerarquía nobiliaria", Construyendo Historia. Estudios en torno a Juan Luis Castellano, Granada, Universidad de Granada, 2013: 17-29.

Andújar Castillo, Francisco y Giménez Carrillo, Domingo Marcos, "Iglesia, negocios y poder entre América, Madrid y el Reino de Granada en el siglo XVII: Bartolomé Marín de Poveda", Francisco Andújar Castillo y Domingo Marcos Giménez Carrillo, Riqueza, poder y nobleza: los Marín de Poveda, una historia familiar del siglo XVII vista desde España y Chile, Almería, Universidad de Almería, 2011: 179-212.

Barrio Moya, José Luis, "La librería del hidalgo vizcaíno don Isidoro Garma de la Puente, Secretario del Rey Felipe V (1717)", Letras de Deusto, 58 (Deusto, 1993): 137-146.

Bertrand, Michel, Grandeur et misère de l'office. Les officiers de finances de Nouvelle Espagne, XVII-XVIII siècles, París, Publications de la Sorbonne, 1999.

Bertrand, Michel, "Los modos relacionales de las elites hispanoamericanas coloniales: enfoques y posturas", Anuario. IEHS, 15 (Tandil, 2000): 117-122.

Bertrand, Michel, “ ¿Grupo, clase o red social? Herramientas y debates en torno a la reconstrucción de los modelos de sociabilidad en las sociedades del Antiguo Régimen", Marta Elena Casaus Arzú y Manuel Pérez Ledesma (eds.), Redes intelectuales y formación de naciones en España y América Latina (1890-1940), Madrid, Universidad Autónoma de Madrid, 2005.

Bertrand, Michel y Lemercier, Claire, "Introducción: ¿en qué punto se encuentra el análisis de redes en Historia?", Redes: Revista Hispana para el análisis de las redes sociales, 21 (Madrid, 2011): 1-12. 
Boissevain, Jeremy y Mitchell, Clyde (coords.), Network Analysis: Studies in Human Interaction, The Hague, Mouton, 1973.

Burkholder, Mark A. y Chandler, David S., De la impotencia a la autoridad: la corona española y las Audiencias en América, México, Fondo de Cultura Económica, 1984.

Cerdá i Ballester, Joseph, Los caballeros y religiosos de la Orden de Montesa en tiempos de los Austrias (1592-1700), Madrid, CSIC, 2014.

Dedieu, Jean-Pierre, "La información de limpieza de sangre", Santiago Muñoz Machado (ed.), Los grandes procesos de la historia de España, Barcelona, Crítica, 2002: 193-208.

Dedieu, Jean-Pierre y Moutoukias, Zacarías, "Approche de la théorie des réseaux", J. L. Castellano y J. P. Dedieu (eds.), Réseaux, familles et pouvoirs dans le monde ibérique à la fin de l'Ancien Régime, París, CNRS, 1998: 7-15.

Domínguez Ortiz, Antonio, “Comercio y blasones. Concesiones de hábitos de Órdenes Militares a miembros del Consulado de Sevilla en el siglo XVII”, Anuario de Estudios Americanos, XXXIII (Sevilla, 1976): 217-256.

Domínguez Ortiz, Antonio, "Unas probanzas controvertidas", Les Cultures Ibériques en devenir. Essais publiés en hommage à la mémorie de Marcel Bataillon (18951977), Paris, Fondation Singer-Polignac, 1979: 181-187.

Domínguez Ortiz, Antonio, "Valoración social de los hábitos de las Órdenes Militares", Ricardo Izquierdo Benito y Francisco Ruiz Gómez (coords.), Las Órdenes Militares en la Península Ibérica, Cuenca, Universidad de Castilla-La Mancha, 2000: 1157-1176.

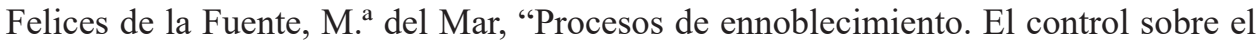
origen social de la nobleza titulada en la primera mitad del siglo XVIII", Francisco Andújar Castillo y María del Mar Felices de la Fuente (eds.), El poder del dinero. Ventas de cargos y honores en la España del Antiguo Régimen, Madrid, Biblioteca Nueva, 2011: 247-273.

Felices de la Fuente, María del Mar, La nueva nobleza titulada de España y América en el siglo XVIII (1701-1746), Almería, Universidad de Almería, 2012.

Fernández Izquierdo, Francisco, “¿Qué era ser caballero de una Orden Militar en los siglos XVI y XVII?", Torre de los Lujanes: Boletín de la Real Sociedad Económica Matritense de Amigos del País, 49 (Madrid, 2003): 141-163.

Fernández Izquierdo, Francisco, "Los caballeros cruzados en el ejército de la Monarquía Hispánica durante los siglos XVI y XVII: ¿anhelo o realidad?”, Revista de Historia Moderna: Anales de la Universidad de Alicante, 22 (Alicante, 2004): $11-60$.

Fernández Izquierdo, Francisco, "Honra y prestigio por la gracia del rey de España: los caballeros del hábito militar en el inicio del reinado del tercer Felipe", Porfirio 
Sanz Camañes (coord.), La monarquía hispánica en tiempos del Quijote, Madrid, Silex, 2005: 189-230.

García León, Antonio, "La malla inconclusa. Veracruz y los circuitos comerciales lusitanos en la primera mitad del siglo XVII", Antonio Ibarra y Guillermina del Valle (coords.), Redes sociales e instituciones comerciales en el imperio español, siglos XVII a XIX, México, Instituto Mora-Facultad de Economía de la UNAM, 2007: 41-83.

Giménez Carrillo, Domingo Marcos, "La venta de hábitos de las Órdenes Militares en el siglo XVII. Entre la ocultación y el delito de simonía", Francisco Andújar Castillo y María del Mar Felices de la Fuente (eds.), El poder del dinero. Ventas de cargos y honores en la España del Antiguo Régimen, Madrid, Biblioteca Nueva, 2011: 301-313.

Giménez Carrillo, Domingo Marcos, Los caballeros de las Órdenes Militares castellanas. Entre Austrias y Borbones, Almería, Universidad de Almería, 2016.

Glesener, Thomas, "Poder y sociabilidad: las elites flamencas en España a través de los expedientes de las Órdenes Militares (siglo XVIII)", Ana Crespo Solana y Manuel Herrero Sánchez (coords.), España y las 17 provincias de los Países Bajos. Una revisión historiográfica (XVI-XVIII), Córdoba, Universidad de Córdoba, 2002: 167-188.

Guerra, François-Xavier, "El análisis de los grupos sociales: balance historiográfico y debate crítico", Anuario. IEHS, 15 (Tandil, 2000): 117-122.

Guerrero Elecalde, Rafael, Las elites vascas y navarras en el gobierno de la monarquía borbónica. Redes sociales, carreras y hegemonía en el siglo XVIII (17001746), Bilbao, Universidad del País Vasco, 2012.

Herrero, Reyes, "La terminología del análisis de redes. Problemas de definición y de traducción”, Política y Sociedad, 33 (Madrid, 2000): 199-206.

Herzog, Tamar, Ritos de control, prácticas de negociación: pesquisas, visitas y residencias y las relaciones entre Quito y Madrid (1650-1750), Madrid, Fundación Ignacio Larramendi, 2000: 15-52.

Ibarra, Antonio, "Redes de circulación y redes de negociantes en el mercado interno novohispano: los mercaderes en el Consulado de Guadalajara 1791-1803", Antonio Ibarra y Guillermina del Valle (coords.), Redes sociales e instituciones comerciales en el imperio español, siglos XVII a XIX, México, Instituto Mora-Facultad de Economía de la UNAM, 2007: 279-294.

Imízcoz, José María, “Comunidad, red social y elites. Un análisis de la vertebración social en el Antiguo Régimen”, José María Imízcoz (dir.), Elites, poder y red social: las élites del País Vasco y Navarra en la Edad Moderna, Bilbao, Universidad del País Vasco, 1996: 13-50. 
Jiménez Moreno, Agustín, "Honores a cambio de soldados, la concesión de hábitos de las Órdenes Militares en una coyuntura crítica: la Junta de Hábitos (16351642)", Enrique Soria Mesa, y José Miguel Delgado Barrado (eds.), Las élites en la época moderna: la monarquía española, Córdoba, Universidad de Córdoba, vol. III, 2009: 155-171.

Lavallé, Bernard, El mercader y el marqués. Las luchas de poder en el Cuzco (17001730), Lima, Fondo Editorial Banco Central de Reserva del Perú, 1988.

Lozares, Carlos, "La teoría de las redes sociales", Papers, 48 (Barcelona, 1996): 103-126.

Lambert-Gorges, Martine, "Le bréviaire du bon enquêteur, ou trois siècles d'information sur les candidats a l'habit des Ordres Militaires", Mélanges de la Casa de Velázquez, 18 (Madrid, 1982): 165-197.

Lohmann Villena, Guillermo, Los americanos en las órdenes nobiliarias, Madrid, CSIC, 1993.

Maruri Villanueva, Ramón, "Poder con poder se paga: títulos nobiliarios beneficiados en Indias (1681-1821)", Revista de Indias, LXIX/246 (Madrid, 2009): 207-240.

Mitchell, J. Clyde, "The Concept and Use of Social Networks", J. Clyde Mitchell (ed.), Social Networks in Urban Situations. Analyses of Personal Relationship in Central African Towns, Manchester, Manchester University Press, 1969: 1-50.

Molina, José Luís, El análisis de redes sociales. Una introducción, Barcelona, Edicions Bellaterra, 2001.

Olival, Fernanda, "Os Áustrias e as reformas das ordenes militares portuguesas", Hispania: Revista española de Historia, 216 (Madrid, 2004): 95-116.

Ponce Leiva, Pilar y Amadori, Arrigo, "Redes sociales y ejercicio del poder en la América hispana: consideraciones teóricas y propuestas de análisis", Revista complutense de historia de América, 34 (Madrid, 2008): 15-42.

Postigo Castellanos, Elena, Honor y privilegio en la Corona de Castilla. El Consejo de las Órdenes y los caballeros de hábito en el siglo XVII, Valladolid, Junta de Castilla y León, 1988.

Requena Santos, Félix, "El concepto de red social". REIS: Revista Española de Investigaciones Sociológicas, 48 (Madrid, 1989): 137-152.

Requena Santos, Félix, "Orígenes sociales del análisis de redes", Requena Santos (ed.), Análisis de redes sociales. Orígenes, teorías y aplicaciones, Madrid, Centro de Investigaciones Sociológicas/Siglo XXI, 2003: 3-14.

Rivero Rodríguez, Manuel (coord.), Nobleza Hispana, Nobleza Cristiana. La Orden de San Juan, Madrid, Polifemo, 2009.

Rodríguez Hernández, Antonio José, "Servir al rey con hombres. Recompensas concedidas a elites y representantes del rey por su colaboración en el reclutamiento 
(1630-1700)", Alicia Esteban Estríngana (ed.), Servir al rey en la Monarquía de los Austrias. Medios, fines y logros del servicio al soberano en los siglos XVI y XVII, Madrid, Silex, 2012: 415-443.

Sanz Ayán, Carmen, "Consolidación y destrucción de patrimonios financieros en la Edad Moderna: Los Cortizos (1630-1715)", Ricardo Robledo Hernández e Hilario Casado Alonso, (coords.), Fortuna y negocios: formación y gestión de los grandes patrimonios (siglos XVI-XX), Valladolid, Universidad de Valladolid, 2002: 73-98.

Sanz Tapia, Ángel, ¿Corrupción o necesidad? La venta de cargos de gobierno americanos bajo Carlos II (1674-1700), Madrid, CSIC, 2009.

Sanz Tapia, Ángel, "Provisión, beneficio y venta de oficios americanos de Hacienda (1632-1700)", Revista complutense de historia de América, 37 (Madrid, 2011): $145-172$.

Sanz Tapia, Ángel, "La justicia en venta. El beneficio de cargos americanos de Audiencia bajo Carlos II (1683-1700)", Anuario de Estudios Americanos, 69/1 (Sevilla, 2012): 63-90.

Scott, John, Social Network Analysis, Londres, Sage Publications, 1997.

Soria Mesa, E., "Genealogía y poder: invención de la memoria y ascenso social en la España Moderna”, Estudis, 30 (Valencia, 2004): 21-56.

Suárez, Margarita, Desafios trasatlánticos; mercaderes, banqueros y el Estado en el Perú virreinal, 1600-1700, Lima, PUCE, Instituto Riva-Agüero, 2001.

Thompson, I. A. A., 'Do ut des: la economía política del 'servicio' en la Castilla Moderna", Alicia Esteban Estríngana, (ed.) Servir al rey en la monarquía de los Austrias. Medios, fines y logros del servicio al soberano en los siglos XVI y XVII, Madrid, Silex, 2012: 283-296.

Turiso Sebastián, Jesús, Comerciantes españoles en la Lima Borbónica. Anatomía de una elite de poder (1701-1761), Valladolid, Universidad de Valladolid, 2002.

Zúñiga, Jean-Paul, "Clan, parentela, familia, individuo: métodos y niveles de análisis”, Anuario. IEHS, (Tandil, 2000): 51-60.

Fecha de recepción: 8 de mayo de 2015 .

Fecha de aceptación: 5 de noviembre de 2015. 


\section{Friendship networks, rural community and venality in Lima with regard to the behaviour of military orders in the late seventeenth century}

With a methodology based on cross-referencing multiple documentary sources and highlighting the value of relational capital in the political and social dynamics of the ancien régime, we study the friendship networks and rural community woven by the people of Lima in the late seventeenth century in a bid to obtain knighthood honours from military orders. We analyse existing links and how networks were created to acquire the orders' crosses and buy the positions in government, the judicial system and the treasury which the monarchy in Madrid had put up for sale.

KeY WORDS: Military Orders; reign of Charles II of Spain; venality; Lima; networks of power. 